NR 875 PROBLEMY ZARZACZANIA, FINANSÓW I MARKETINGU NR 41, t. 12015

DOI: $10.18276 /$ pzfm.2015.41/1-12

\author{
BRUNO SCHIVINSKI ${ }^{1}$
}

Gdansk University of Technology

PRZEMYSŁAW ŁUKASIK ${ }^{2}$

Maria Curie-Skłodowska University in Lublin

\title{
IMPLEMENTING THE CONSUMER-BASED BRAND EQUITY SCALE FOR BEER BRANDS - A TYSKIE AND ŻYWIEC CASE STUDY
}

\begin{abstract}
Summary
The concept and management of brand equity is of great importance to scholars and managers. In this article, brand equity is approached from the consumers' point of view i.e., consumer-based brand equity (CBBE) in the context of two beer brands offered in Poland - Tyskie and Żywiec. The objective of this article is to demonstrate how managers can implement the CBBE scale as an audit and monitoring instrument to their brands. A sample of 311 respondents was analyzed to generate scores for brand awareness, brand associations, perceived quality, and brand loyalty. Additionally, scores for overall brand equity were also generate. The results demonstrated that the scores of brand awareness for Żywiec was higher than Tyskie, however, Tyskie scored higher for brand associations, perceived quality, and brand loyalty. The brand Tyskie also achieved better overall brand equity scores than Żywiec.
\end{abstract}

Keywords: consumer-based brand equity, beer brands, brand awareness

\section{Introduction}

The concept of brand equity is a core-marketing asset that creates a relationship that forms distinctive ties between companies and consumers and that fosters long-term buying behavior. ${ }^{3}$ The understanding of the concept of brand equity

\footnotetext{
${ }^{1}$ bruno.schivinski@gmail.com.

2 przemyslaw.lukasik@umcs.lublin.pl.

${ }^{3} \mathrm{G}$. Christodoulides, L. de Chernatony, Consumer-based brand equity conceptualisation and measurement: A literature review, "International Journal of Market Research" 2010, No. 52 (1), p. 43-65;
} 
and its growth levers competitive barriers and drives brand wealth. ${ }^{4}$ In literature, the conceptualization and measurement of brand equity has been tackled from two major perspectives. Some researchers have focused on the firm-based perspective of the construct, while others have underlined consumer-based perceptions. ${ }^{5}$ Nevertheless, despite the importance of firm-based approach to brand equity, the dominant stream of research has been based upon the consumer, focusing on cognitive psychology and memory structures. ${ }^{6}$ In this article, brand equity is approached by the consumers' standpoint. This approach is called consumerbased brand equity (hereafter CBBE).

Although several researchers have tackled the methodological and theoretical aspects of $\mathrm{CBBE},{ }^{7}$ little attention was given to the practical applicability of the scales to measure brand equity. Therefore the objective of this article is to demonstrate how managers can implement the CBBE scale as an audit and monitoring instrument to their brands. Additionally, the CBBE scale provided in this article can guide brand executives on what constitutes CBBE (dimensions) and what aspects (items) comprise those dimensions.

The article is organized as follows. The first section presents a literature review of the conceptual domain of CBBE. In the second section, we provide a description of our research methodology. The third section presents the results of the study. Finally, the last section provides a summary and a discussion of our results, as well as, practical implications for practitioners. Research limitations and suggestions for further studies are also included in this article.

\section{Literature review}

The operationalization of the CBBE can be classified as direct or indirect. The direct approach endeavors to directly capture the phenomenon by concen-

\footnotetext{
J. Kall, R. Kłeczek, A. Sagan, Zarządzanie marka, Oficyna a Wolters Kluwer business, Kraków 2006, p. $176-178$.

${ }^{4}$ G. Christodoulides, L. de Chernatony, Consumer-based brand ..., p. 43-65; M. Dębski, Kreowanie silnej marki, PWE, Warszawa 2009, p. 34.

${ }^{5}$ B. Schivinski, P. Łukasik, Rozwój badań nad kapitałem marki bazującym na konsumencieprzeglad literatury, "Marketing i Rynek" 2014, No. 11, p. 74-80.

${ }^{6}$ K.L. Keller, D.R. Lehmann, Brands and branding: Research findings and future priorities, „Marketing Science” 2006, No. 25 (6), p. 740-759.

7 e.g. B. Yoo, N. Donthu, Developing and validating a multidimensional consumer-based brand equity scale, "Journal of Business Research" 2001, No. 52 (1), p. 1-14; R. Pappu et al., Consumerbased brand equity: improving the measurement - empirical evidence, "Journal of Product \& Brand Management” 2005, No. 14 (3), p. 143-154; I. Buil et al., A cross-national validation of the consumerbased brand equity scale, "Journal of Product \& Brand Management" 2008, No. 17 (6), p. 6-17.
} 
trating on consumer's preferences or utilities. On the other hand, the indirect approach captures brand equity through its demonstrable manifestations. ${ }^{8}$ This article is focus on the indirect approach.

According to D.A. Aaker, CBBE is defined as "a set of brand assets and liabilities linked to a brand, its name and symbol that add to or subtract from the value provided by a product or service to a firm and/or to that firm's customers". 9 To capture the concept of consumer-based brand equity, in this article it was drawn on four of D.A. Aaker's five-core brand equity dimensions i.e., brand awareness, brand associations, perceived quality, and brand loyalty. The fifth dimension - other proprietary brand assets, is usually not included in the CBBE framework, as it is not directly related to individuals, but to companies.

Brand awareness is delimitated as "the ability of a potential buyer to recognize or recall that a brand is a member of a certain product category". ${ }^{10}$ Therefore, this dimension reflects the strength of the brand in the customer's mind.${ }^{11}$ Brand associations are defined as "anything linked to the memory of a brand". ${ }^{12}$ Thus, brand associations are thought to contain the meaning of the brand for consumers and can derive from an extensive range of sources, varying according to their favorability, strength, and uniqueness. ${ }^{13}$ Moreover, those associations have difference levels of strength, and the consumer's link to a brand tends to be stronger when it is based on frequent repetitions of stimulus or exposure than when it is based on infrequent exposure. ${ }^{14}$ Perceived quality is defined as "the consumer's judgment about a product's overall excellence or superiority". ${ }^{15}$ The consumer's perception of quality has four main characteristics i.e., it is different from the objective or actual quality of the product; it is an abstract conception, rather than a specific attribute of the product; it is a global assessment that resembles attitude; and it is a judgment made within a consumer's evoked set. ${ }^{16}$ Additionally, perceived quality delivers value by differentiating a brand from its competitors and providing the consumer with reasons to purchase it. ${ }^{17}$ Finally, brand loyalty is

\footnotetext{
${ }^{8}$ B. Schivinski, P. Łukasik, Rozwój badań nad kapitałem..., p. 74-80.

9 D.A. Aaker, Managing brand equity: Capitalizing on the value of a brand name, The Free Press, New York 1991, p. 15.

${ }^{10}$ Ibidem, p. 61

${ }^{11}$ I. Buil et al., A cross-national validation..., p. 3.

${ }^{12}$ D.A. Aaker, Managing brand equity..., p. 109.

${ }^{13}$ K.L. Keller, Conceptualizing, measuring, and managing customer-based brand equity, ,Journal of Marketing" 1993, No. 57 (January), p. 5.

${ }^{14}$ Ibidem, p. 5-6.

${ }^{15}$ D.A. Aaker, Managing brand equity..., p. 85.

16 V.A. Zeithaml, Consumer perceptions of price, quality, and value: A means-end model and synthesis of evidence, ,Journal of Marketing” 1998, No. 52 (July), p. 3.

${ }^{17}$ D.A. Aaker, Managing brand equity..., p. 85-86.
} 
defined as "the attachment that a customer has to a brand". ${ }^{18}$ Therefore, brand loyalty is based on the consumer's behavioral perspective, focusing on product purchasing repetition or on an attitudinal perspective, which emphasizes a personal commitment to a set of unique values related to the brand and the tendency to be loyal to a brand, prioritizing the brand as a first choice for purchase. ${ }^{19}$

\section{Methodology}

This study is an extension of a research that aimed to improve the actual instruments for measuring consumer-based brand equity. ${ }^{20}$ The data were collected online using the CAWI technique. ${ }^{21}$ Only one subject was allowed to participate in the survey per computer. The average age of respondents was 33 years, 24\% had at least some college education, $50.5 \%$ were female, and the median monthly household income was in the 2500 PLN to 4500 PLN ( 760 USD to 1360 USD) range. For the analysis, it was used a sample of 148 entries to Tyskie and 163 entries to Żywiec, therefore, resulting in a total sample size of 311 respondents. The items used during this stage of the research were measured using a sevenpoint Likert scale ranging from 1 for "strongly disagree" to 7 for "strongly agree". Five items each measured brand awareness, associations, and loyalty. Four items measured perceived quality. The final instrument resulted in a scale of nineteen indicators. ${ }^{22}$ To measure the overall consumer-based brand equity of each brand it was used a combination of eight items drawn from the four CBBE dimensions. ${ }^{23}$

\section{Data analysis and results}

To establish reliability of the scales, it was used Cronbach's alpha and composite reliability (CR). The alpha coefficients ranged from 0.93 to 0.96 , higher than the recommended threshold value of $0.7 .^{24}$ The $\mathrm{CR}$ values ranged from 0.93

\footnotetext{
${ }^{18}$ Ibidem, p. 39.

${ }^{19}$ Ibidem, p. 40.

${ }^{20}$ B. Schivinski, D. Dąbrowski, The consumer-based brand equity inventory: Scale construct and validation, GUT FME Working Paper Series A. Gdansk (Poland): Gdansk University of Technology, Faculty of Management and Economics 2014, No. 4 (22), p. 2-24.

${ }^{21}$ R. Mącik, M. Korba, Wiarygodność pomiaru w badaniach mixed-mode: Porównanie efektów stosowania PAPI i CAWI, Prace Naukowe Uniwersytetu Ekonomicznego we Wrocławiu No. 96, Wrocław 2010, p. 199-210.

${ }^{22}$ B. Schivinski, D. Dąbrowski, The consumer-based ..., p. 20.

${ }^{23}$ Ibidem.

${ }^{24}$ J.F. Hair Jr. et al., Multivariate data analysis, Pearson Education Limited, Harlow 2014, p. 125.
} 
to 0.96 , meeting the standard minimum threshold of $0.7 .{ }^{25}$ These results determine that the scales used to measure CBBE for both beer brands are reliable and well calibrated.

For convergent validity, three criteria must be achieved: first, the model fit must be adequate; second, the lambda values must be significant and greater than 0.30; and third, the average variance extracted (AVE) must exceed 0.50. All three criteria were met during the study. To achieve discriminant validity, it was applied the Fornell-Larcker test, which requires that the square root AVE for each construct is greater than any inter-construct correlations. ${ }^{26}$ All the constructs from the CBBE scale met this criterion. The reliability, convergent and discriminant validity scores are summarized in table 1.

Table 1

Reliability, convergent and discriminant validity table chart

\begin{tabular}{|l|c|c|c|c|c|c|c|}
\hline \multicolumn{1}{|c|}{ Factors } & $\begin{array}{c}\text { Cronbach's } \\
\text { alpha }\end{array}$ & CR & AVE & $\begin{array}{c}\text { Brand as- } \\
\text { sociations }\end{array}$ & $\begin{array}{c}\text { Brand } \\
\text { awareness }\end{array}$ & $\begin{array}{c}\text { Perceived } \\
\text { quality }\end{array}$ & $\begin{array}{c}\text { Brand } \\
\text { loyalty }\end{array}$ \\
\hline $\begin{array}{l}\text { Brand } \\
\text { associations }\end{array}$ & 0.93 & 0.93 & 0.75 & 0.87 & & & \\
\hline $\begin{array}{l}\text { Brand } \\
\text { awareness }\end{array}$ & 0.96 & 0.96 & 0.84 & 0.24 & 0.91 & & \\
\hline $\begin{array}{l}\text { Perceived } \\
\text { quality }\end{array}$ & 0.94 & 0.94 & 0.80 & 0.84 & 0.18 & 0.89 & \\
\hline Brand loyalty & 0.96 & 0.96 & 0.84 & 0.73 & 0.01 & 0.71 & 0.91 \\
\hline
\end{tabular}

Note: The square roots of the average variance extracted (AVE) are marked in italics

Source: own elaboration.

Proceeding with the confirmatory analyses, all four latent variables were included in a single confirmatory factor analysis (CFA) model executed using the maximum likelihood estimation (ML). During CFA, the model demonstrated a good fit. The chi-square/df value was 1.84 , the CFI value was 0.92 , and the TLI value was 0.90 . All values were in the ranges of the acceptable thresholds and indicated a good fit of the model to the data. ${ }^{27}$ These results inform that the consumer-based brand equity model for the two beer brands is adequate to the sample of the population.

${ }^{25} \mathrm{~W}$. Chin et al., A partial least squares latent variable modeling approach for measuring interaction effects: results from a Monte Carlo simulation study and voice mail emotion/adoption, "Information Systems Research" 2003, No. 14 (2), p. 189-217.

${ }^{26}$ C. Fornell, D. Larcker, Evaluating structural equation models with unobservable variables and measurement error, "Journal of Marketing Research" 1981, No. 18 (1), p. 39-50.

${ }^{27}$ J.F. Hair Jr. et al., Multivariate data analysis ..., p. 584. 
A summary of CBBE scores for the brands Tyskie and Żywiec are given in table $2 .{ }^{28}$ Comparing the consumer-based brand equity scores for both brands, it is noticeable that consumers are more aware of the existence of the brand Żywiec (mean 6.52 std. 1.27) than Tyskie (mean 6.27 std. 1.43). This dimension is the base point to build up a strong brand. In the CBBE framework, brand awareness is not only limited to a general recognition of the brand among competitors, but it also takes in account the ability of the consumers to recall the logo of the brands, and the aptitude to name different products under the same brand name. A score higher than six should be considered to be a very good score. ${ }^{29}$ Therefore, it reflects that the general marketing communication strategies for both companies are working well.

Table 2

Consumer-based brand equity scores

\begin{tabular}{|l|c|c|c|c|c|}
\hline \multicolumn{1}{|c|}{ CBBE dimension } & Brand & Minimum & Maximum & Mean & $\begin{array}{c}\text { Std. } \\
\text { Deviation }\end{array}$ \\
\hline \multirow{2}{*}{ Brand awareness } & Tyskie & 1 & 7.0 & 6.27 & 1.43 \\
\cline { 2 - 6 } & Żywiec & 1 & 7.0 & $\mathbf{6 . 5 2}$ & 1.27 \\
\hline \multirow{2}{*}{ Brand associations } & Tyskie & 1 & 7.0 & $\mathbf{4 . 9 6}$ & 1.52 \\
\cline { 2 - 6 } & Żywiec & 1 & 7.0 & 4.41 & 1.66 \\
\hline \multirow{2}{*}{ Perceived quality } & Tyskie & 1 & 7.0 & $\mathbf{4 . 5 9}$ & 1.69 \\
\cline { 2 - 6 } & Żywiec & 1 & 7.0 & 4.13 & 1.84 \\
\hline \multirow{2}{*}{ Brand loyalty } & Tyskie & 1 & 6.6 & $\mathbf{3 . 3 8}$ & 1.57 \\
\cline { 2 - 6 } & Żywiec & 1 & 7.0 & 2.53 & 1.82 \\
\hline \multirow{2}{*}{ Overall brand equity } & Tyskie & 1 & 7.0 & $\mathbf{4 . 0 5}$ & 1.67 \\
\cline { 2 - 6 } & Żywiec & 1 & 7.0 & 3.40 & 1.66 \\
\hline
\end{tabular}

Source: own elaboration.

Analysis the scores for brand associations, the brand Tyskie scored higher (mean 4.96 std. 1.52) than the competitor brand (mean 4.41 std. 1.66). A score higher than four for brand associations is recommended when building consumerbased brand equity, as this dimension measures the positive emotions that consumers feel about a brand (e.g., liking the brand, believing that brand has a good image, and having good memories related to previous purchases).

${ }^{28}$ A comparison of statistically significance of scores across brands is out of the scope of this article. Although such comparisons could be assessed with Mann-Whitney U or t tests, in this article focus was given in the practical application of the CBBE scale as an audit instrument. Therefore, the main interest of managers is to evaluate the raw scores of each CBBE dimension.

${ }^{29}$ Although there is no consensus in literature about the benchmarks for determining low and high scores of CBBE, in this article it was adopted the score of 4 as a middle point - as the scales were measured using a seven-point Likert scale. Therefore, scores higher than 4 were considered high scores, and consequently, scores bellow 4 were considered low scores. 
The next dimension in the analysis is perceived quality. Both brands scored above four. The brand Tyskie showed a perceived quality score higher (mean 4.59 std. 1.69) than Żywiec (mean 4.13 std. 1.84). The score of Żywiec is slightly above the middle point of the scale, thus indicating that the consumers' perception of the quality of their beer is moderate. A deeper analysis is recommended in order to improve the score of perceived quality dimension. The consumer's perception of quality is a reflection of several factors, which not comprise only the real quality of the product, but also the company's communication strategy, product positioning, package, relation price-benefit, and other marketing and branding tools. As an example, it may happen that the real quality of a beer is high, however, the label of the bottle is made of a poor quality material and it was not designed to reflect premium quality. Even with a beer of better quality than competitors, this brand will have lower scores for perceived quality than competitors that offer a superior presentation of the product.

Finally, the last dimension of CBBE analyzed is brand loyalty. This construct is the ultimate goal when building a strong and health brand. Brand loyalty is strongly related to purchase intention, brand extensions, and predisposition of the consumers to pay a premium price. ${ }^{30}$ In this study, consumers reveal that their loyalty towards both beer brands is weak, as demonstrated by the scores bellow the middle point of the scale. Tyskie scored higher (mean 3.38 std. 1.57) than the competing brand (mean 2.53 std. 1.82), however, scores bellow four demonstrate a fragile link of CBBE. To increase brand loyalty is suggested that marketing efforts to be directed to the improvement of both brand associations and perceived quality, as those dimensions are antecedents of brand loyalty. ${ }^{31}$

To summarize the four dimensions it was included in the analysis the overall brand equity score. This score showed to be moderated for Tyskie (mean 4.05 std. 1.67) and to be weak for Żywiec (mean 3.40 std. 1.66). As overall brand equity is a summation of the four dimensions of CBBE, to increase its score to a desirable level, it is necessary to remedy the dimensions that scored the lowest.

\section{Summary and discussion}

Before managers can build CBBE they should understand what dimensions make the construct manifest. When practitioners decide to build CBBE they need to consider a heterogeneous range of aspects. Therefore, brand managers need to

\footnotetext{
${ }^{30}$ B. Schivinski, P. Łukasik, Rozwój badań nad kapitałem ..., p. 74-80.

${ }^{31}$ Ibidem.
} 
find answers to questions such as "Do consumers know our brand? Can consumers recognize its logo and the brand product among other products? Do consumers like our brand and have good feelings about it? Do consumers perceive our brand products to be of superior quality than its alternatives? Are consumers loyal and attached to the brand to a point that they buy its products instead of competitors'?" Only when such questions are addressed brand managers will be considering the breadth of issues that convey the domain of CBBE. In this article, the practical management of $\mathrm{CBBE}$ is approached in the context of two Polish beer brands.

When using the CBBE scale managers can benefit from an instrument for auditing and tracking the consumer's perceptions of brand equity. If the instrument is used over a period of time the measurement results allow brand managers to assess the effectiveness of marketing and brand management strategies. Therefore, corrective actions can be taken if necessary. In a similar way, brand managers are also able to audit and track CBBE from other brands in the market.

As previously mentioned, this study has limitations that influence in the generalization of the findings. The main limitation is concerned to the sample size. The results presented in the study reflect only a small sample of consumers. To have a general understanding of the Polish market, this study should be repeated with a significantly large sample (above 1000 consumers) across Poland for each brand. This would give a complete view of how the consumer's perceptions of both brands differ across the country. Additionally, the analysis was not extended to show the statistical differences across groups. Such tests are recommended when pointing out differences of scores.

\section{Bibliography}

Aaker D.A., Managing brand equity: Capitalizing on the value of a brand name, The Free Press, New York 1991.

Buil I. et al., A cross-national validation of the consumer-based brand equity scale, "Journal of Product \& Brand Management" 2008, No. 17 (6).

Chin W. et al., A partial least squares latent variable modeling approach for measuring interaction effects: results from a Monte Carlo simulation study and voice mail emotion/adoption, "Information Systems Research" 2003, No. 14 (2).

Christodoulides G., de Chernatony L., Consumer-based brand equity conceptualisation and measurement: A literature review, "International Journal of Market Research" 2010, No. 52 (1).

Dębski M., Kreowanie silnej marki, PWE, Warszawa 2009.

Fornell C., Larcker D., Evaluating structural equation models with unobservable variables and measurement error, "Journal of Marketing Research" 1981, No. 18 (1).

Hair Jr. J.F. et al., Multivariate data analysis, Pearson Education Limited, Harlow 2014.

Kall J., Kłeczek R., Sagan A., Zarzadzanie marka, Oficyna a Wolters Kluwer business, Kraków 2006. 
Keller K.L., Conceptualizing, measuring, and managing customer-based brand equity, “Journal of Marketing" 1993, No. 57 (January).

Keller K.L., Lehmann D.R., Brands and branding: Research findings and future priorities, "Marketing Science" 2006, No. 25 (6).

Mącik R., Korba M., Wiarygodność pomiaru w badaniach mixed-mode: Porównanie efektów stosowania PAPI $i$ CAWI, Prace Naukowe Uniwersytetu Ekonomicznego we Wrocławiu No. 96, Wrocław 2010.

Pappu R. et al., Consumer-based brand equity: Improving the measurement - empirical evidence, "Journal of Product \& Brand Management" 2005, No. 14 (3).

Schivinski B., Dabrowski D., The consumer-based brand equity inventory: Scale construct and validation, „GUT FME Working Paper Series A. Gdansk (Poland): Gdansk University of Technology, Faculty of Management and Economics" 2014, No. 4 (22).

Schivinski B., Łukasik P., Rozwój badań nad kapitałem marki bazującym na konsumencie - przeglad literatury, "Marketing i Rynek" 2014, No. 11.

Yoo B., Donthu N., Developing and validating a multidimensional consumer-based brand equity scale, "Journal of Business Research" 2001, No. 52 (1).

Zeithaml V. A., Consumer perceptions of price, quality, and value: A means-end model and synthesis of evidence, "Journal of Marketing" 1988, No. 52 (July).

\section{ZASTOSOWANIE SKALI DO POMIARU POSTRZEGANEGO PRZEZ KONSUMENTA KAPITALU MAREK WZGLEDEM MAREK PIWA - STUDIUM PRZYPADKU TYSKIE I ŻYWIEC}

\section{Streszczenie}

Problem zarządzania kapitałem marki ma istotne znaczenie dla badaczy i menedżerów. W niniejszym artykule kapitał marki jest rozpatrywany z punktu widzenia konsumenta, czyli jako postrzegany przez konsumenta kapitał marki (CBBE - consumer-based brand equity) w odniesieniu do dwóch oferowanych w Polsce marek piwa - Tyskie i Żywiec. Celem artykułu jest prezentacja tego, w jaki sposób menedżerowie mogą wykorzystać skalę do pomiaru CBBE jako instrumentu kontroli i monitoringu zarządzanych przez nich marek. Do pomiaru świadomości analizowanych marek, skojarzeń z markami, postrzeganej jakości oraz lojalności wobec marek wykorzystano dane uzyskane od 311 respondentów. Obliczono także ogólny kapitał obydwu marek. Otrzymane wyniki wskazują, że świadomość marki Żywiec jest większa niż marki Tyskie, jednak marka Tyskie osiągnęła lepsze wyniki w zakresie skojarzeń z marką, postrzeganej jakości oraz lojalności wobec marki. Marka Tyskie ma także wyższy od marki Żywiec ogólny kapitał marki.

Słowa kluczowe: kapitał marki bazujący na kliencie, marki piwa, świadomość marki 
